\title{
Challenges and opportunities for traditional herbal medicine today with special reference to its status in India
}

\author{
Bushra Parveen*, Abida Parveen**, Rabea Parveen***, Sayeed Ahmad****, Minhaj Ahmad***** and Muhammad Iqbal* \\ *Department of Pharmaceutical Medicine, School of Pharmaceutical Education and Research, Jamia Hamdard (Deemed University), \\ Hamdard Nagar, New Delhi, 110062, India \\ **Centre for Translational and Clinical Research, School of Interdisciplinary Studies, Jamia Hamdard (Deemed University), Hamdard Nagar, \\ New Delhi, 110062, India \\ ***Department of Biosciences, Jamia Millia Islamia (Central University), Jamia Nagar, New Delhi, 110025, India \\ ****Department of Pharmacognosy and Phytochemistry, School of Pharmaceutical Education and Research, Jamia Hamdard (Deemed University), \\ Hamdard Nagar, New Delhi, 110062, India \\ *****Department of Surgery, School of Unani Medical Education and Research, Jamia Hamdard (Deemed University), Hamdard Nagar, \\ New Delhi, 110062, India \\ Formerly with Department of Botany, School of Chemical and Life Sciences, Jamia Hamdard (Deemed University), Hamdard Nagar, New Delhi, \\ 110062, India
}

\section{Article Info}

\section{Article history}

Received 14 August 2020

Revised 5 October 2020

Accepted 7 October 2020

Published online 30 December 2020

\section{Keywords}

Herbal products

Medicinal-plant conservation

Plant characterization

Reverse pharmacology

Traditional medicine

\begin{abstract}
As per the definition approved by the World Health Organization (WHO), the term herbal medicine applies to all those medicines that occur in the form of plants, plant parts (such as roots, rhizomes, stem, bark, wood, leaves, flowers, fruits, seeds or their active ingredients), herbal preparations, or the finished products containing these materials singly or in combinations. The major strengths of herbal medicine include absence of adverse side effects in general, long-lasting curative impact and, sometimes, cost-effectiveness. However, duration of treatment is relatively long and, in some cases, herbal drugs may react with modern medicine, if taken together. The cause of herbal medicine is currently suffering from (a) decline in species richness, (b) negligence towards plant systematics in higher education, (c) lack of cultivation practices and agro-technology for majority of medicinal and aromatic plants, (d) little financial support for research in conservation biology, (e) and shortage of sophisticated research facilities for quality control. Immediate steps required to be taken for protection and promotion of herbal medicine include (a) in situ and ex situ conservation of the fast-dwindling wealth of medicinal plants; (b) their large-scale cultivation, possibly under buy-back agreement with farmers; (c) authentication and characterization of medicinal plant species based on scientific parameters; (d) standardization and quality control of herbal products under preparation, and (e) generation of data on clinical evidence for efficacy and safety of herbal drugs. All these aspects are discussed in this review with special emphasis on the status and scope of traditional herbal medicine in the Indian sub-continent.
\end{abstract}

\section{Introduction}

'Herb' is a specific term in the botanical literature, which applies strictly to non-woody vascular plants, such as the annual, biennial and some perennial crops (including most of the monocot species), which do not have persistent woody stems. However, in the world of pharmacy, the term is used in a wider sense, like a synonym of 'plant', and covering all herbs, shrubs and trees. The term Herbal medicine (also called Botanical medicine or Phytomedicine), encompasses all those medicinal products, which are prepared by using plants, plant parts or plant products, with a minimal or no

Corresponding author: Dr. Muhammad Iqbal

Professor, Formerly with Department of Botany, School of Chemical and Life Sciences, Jamia Hamdard (Deemed University), Hamdard Nagar, New Delhi, 110062, India

E-mail: iqbalg5@yahoo.co.in

Tel.: +91-9873137770

Copyright (C) 2020 Ukaaaz Publications. All rights reserved.

Email: ukaaz@yahoo.com; Website: www.ukaazpublications.com chemical manipulation (Iqbal, 2018). In a broader sense, herbal medicines include herbs, herbal materials (leaves, flowers, fruits, seeds, stems, woods, barks, roots, rhizomes or other plant parts and active ingredients), herbal preparations as well as the finished products that contain plants, plant parts or other materials of plant origin or combinations thereof as their main ingredients (WHO, 2019).

Plants produce primary metabolites that are directly involved in processes of their own development, growth and reproduction, but a large number of secondary metabolites (also known as natural products) are then synthesized from primary metabolites by chemical transformations of molecules through a number of enzymatic reactions (Thangavel et al., 2014). According to their biosynthetic pathways, secondary metabolites are classified as (a) phenols, (b) terpenes and (c) alkaloids. Phenols (or phenolics) consist of a hydroxyl group (-OH) bonded direct to an aromatic hydrocarbon group, and are classified further usually on the basis of the number of carbons, and have flavonoids as their largest 
component group, which includes various compounds such as flavonols, flavones, flavanones, flavan-3ols (catechins), isoflavonoids and anthocyanidins. Terpenes, which are derived biosynthetically from units of isoprene, constitute a large class of organic compounds with strong smell. On being modified chemically, they give rise to terpenoids (or isoprenoids). Alkaloids, another class of natural products, mostly contain basic nitrogen atoms. Amino acids, such as ornithine, lysine, tyrosine, phenylalanine, tryptophan, histidine aspartic acid and anthranilic acid, are the biological precursors of most of the alkaloids (Taiz, 2010; Stavroula and Rahul, 2016).

Callus and suspension cultures have long been used for the production of active principles in medicinal plant species. Recent advances in plant genetics and recombinant DNA technology have given a boost to our understanding of the biosynthesis of secondary metabolite, which act basically as protective substances for plants against pathogens or herbivores, but most of them are also useful for humans due to their therapeutic properties. Thus, the presence of some specific secondary metabolites in a plant makes it a medicinal plant. The quantity and quality of these metabolites are affected by environmental factors, like temperature, light, water, nutrients, salinity and a variety of pollutants (Farooqi and Haque, 2011). For instance, medicinal plants that grow under semi-arid conditions normally produce greater amounts of secondary metabolites than the identical plants of the same species growing under moderate climatic conditions (Selmar and Kleinwächter, 2013; Kleinwächter and Selmar, 2015). Under drought stress, the metabolic paths are pushed towards the synthesis of compounds like isoprenoids, phenols or alkaloids. Environmental pressures generally cause oxidative stress within the plant tissues, which in turn hampers the yield of plants and often reduces the quantity and quality of their natural products (Qureshi et al., 2011, 2013).

\section{The state-of-the-art of herbal medicine}

All traditional systems of medicine such as Ayurveda, Unani and Chinese, and even homeopathy and naturopathy, are primarily plant-based. However, because of being regarded as primitive and unscientific, these medical practices were ignored and even declared illegal by authorities during the colonial era. In the early 19th century, when chemical analysis came in place, scientists began to extract and modify the active medicinal compounds present in plants and use them as ingredients of allopathic medicines. Later, chemists started synthesizing these compounds and developing their own versions of plant compounds. Not less than $25 \%$ of the allopathic prescription drugs contain at least one active ingredient derived from plants (Barrett et al., 1999). Modern research has proved that herbal medicines are as effective as conventional medicines, besides being exceedingly safe. Estimations suggest that out of the estimated 250-400 thousand plant species of the world, only $15 \%$ have been investigated phytochemically and $6 \%$ screened systematically for their biological activity (Patwardhan et al., 2005). Over $60 \%$ of the drugs in clinical use contain natural compounds or their derivatives, and more than 120 chemical products/moieties from herbal sources are being used as lifesaving drugs (Yuan et al., 2016; PBW, 2018).

Herbal medicines have earned reputation as "the people's medicines" because of their easy accessibility, claimed safety, and easy preparation, and are now gradually scorning the mainstream systems of medical treatment in many countries, as improvements in quality control of herbal drugs along with advances in clinical research are now molding the general opinion in their favour. In some Asian and African countries, $80 \%$ population depends on traditional herbal medicines for primary healthcare, whereas in many developed countries $70-80 \%$ of the population uses complementary or alternative medicines (CAMs) comprising primarily of herbal products. In Japan, 60-70 per cent of allopathic doctors prescribe 'kampo' drugs (largely composed of herbal products). About 70\% German physicians prescribe plant-based medicines (Ghani, 2013). The WHO Regional Office for the Americas reports that $71 \%$ and $40 \%$ of the populations in Chile and Colombia, respectively, use herbal medicine. Nearly $46 \%, 49 \%$ and $70 \%$ of the populations in Australia, France and Canada, respectively, are supposed to use CAM. About 158 million Americans use the natural or herbal medicine (Ghani, 2013).

Since, the chemical antibiotics often render the causal pathogen strains drug-resistant, it is desirable to explore natural molecules that have a broad-spectrum action and do not induce resistance in the microbial pathogens. As plants protect themselves by producing, inter alia, antimicrobial peptides, which exhibit selectivity for prokaryotes and minimize the problem of engendering microbial resistance, these peptides seem to have a remarkable clinical value as well (Khanum et al., 2014). The current investigations on Corona-vaccine engineering have indicated that self-assembling peptide nanofibers may turn out as an effective SARS-CoV-2 vaccine (Black, 2020). The 'omics' studies have also provided new impetus to herbal medicine research. Since genomics can find gene clusters and gene duplication events responsible for specialized metabolism, it may help in identifying the genemetabolite links in plants. As most of the new herbal drugs are derived from secondary metabolites (alkaloids, terpenoids and phenolic compounds), gene functions in medicinal plants need to be analysed systematically through sequencing, assembling and annotating their genomes. Only a few well-assembled herbal genomes have been released so far. However, genomic information, together with the proteomic, transcriptomic and metabolomic data, can be used to predict the secondary metabolite pathways of medicinal plants (Chakraborty, 2018).

As the biosynthesis of secondary metabolites is the summation of genetic and physiological plant responses to environmental factors, enough differences in the makeup of bioactive compounds, such as flavonoids and saponins, may be seen within a single species (Hashiguchi et al., 2017a, Lee et al., 2017). Also, many bioactive compounds in medicinal plants are heavily modified by chemical reactions. Multiple glycosylation steps that form branch points within the biosynthetic pathways often lead to production of compounds of diverse subfamilies with varied therapeutic properties (Ehlting et al., 1999; Plaza et al., 2014). Sometimes, one component in a multi-herbal formula is identified as an active principle, but the mixture also includes other ingredients that are likely to cause potentiating or antagonistic effects, which are crucial for assessing the pharmacological action of the formulation (Hashiguchi et al., 2017b), but these compounds and their biosynthetic pathways remain undiscovered. Proteomics has helped in understanding the metabolism and changes in metabolic pathways caused by external factors (Zaynab et al., 2018). It has been noted, for example, that proteins involved in alkaloid biosynthesis, such as codeinone 
reductase, strictosidine synthase, tryptophan synthase and 12-oxophytodienoate reductase, play a significant role in the production of secondary metabolites (Aghaei and Komatsu, 2013).

As the herbal drugs and botanicals are composed of hundreds of bioactive molecules with diverse chemistry and hence have possibilities of modulating many targets, genes and diseases in a collective and safe manner, the situation gives rise to the concept of a multicomponent, multi-targeting and synergistic polypharmacology, and supports the holistic approach of treatment of the Indian and other traditional healing systems. Identification of complete sets of metabolites in extracts/botanicals/plants used as medicine will hopefully help in the networking of multiple mechanisms of herbal drugs action. Several reports have appeared recently on the metabolomic profiling of some Indian medicinal plants, such as those on Banana fruit extract (Fahim et al., 2019), Gudmar leaf extract (Parveen et al., 2019), Kasni seed extract (Chandra et al., 2018), Papaya leaf extract (Anjum et al., 2017), Pathar phodi leaf extract (Ahmad et al., 2017), Palash flowers (Khan et al., 2017), Shahjan leaf extract (Khan et al., 2017a), Makoi fruit extract (Chester et al., 2017), Kutki extract (Zaheeruddin et al., 2017), Pashan-bhed extract (Sharma et al., 2017) and Brahmi extract (Mallick et al., 2017). These reports have substantiated the traditional claims about these medicines by depicting the mechanisms of their pharmacological actions.

A great many modern medicines are now being extracted from plants (Ali, 2020). The World Health Organization (WHO) estimates that about $25 \%$ of modern drugs used in the United States are plant-derived. More than 120 active compounds isolated from higher plants are now used in the modern allopathic medicine and the modern therapeutic use of about $80 \%$ of them endorses the traditional use of plants from which they are extracted. Nearly 7,000 plant-based medicinal compounds are included in the pharmacopoeia of modern drugs. The market for herbal medicine is on the rise and is growing at the rate $7-30 \%$ annually. To cite a few examples, annual revenue from herbal medicinal products reached US\$ 17 billion (in 2002) in the USA, 5 billion (in 2003-2004) in the Western Europe, 14 billion (in 2005) in China, and 160 million (in 2007) in Brazil (Ghani, 2013). In Malaysia, about US\$ 500 million is spent annually on herbal health care, compared to nearly US\$ 300 million on allopathic medicine. The global market value of herbal medicine was US\$ 62 billion in 2004, 80 billion in 2013, and is likely to surpass USD\$ 129 billion by the year 2023 with a strong CAGR (compound annual growth rate) over the period 2018-2023, as estimated by the 'Market Research Future' (MRFR, 2019). WHO expects the herbal market to grow to US\$ 7 trillion by the year 2050 (Marichamy et al., 2014). The market of herbal product is also likely to expand in the near future in view of the growing demand for plant-based veterinary medicine that may not cause negative impacts on animal health and works as the potential alternative to the conventional synthetic pest-control products. For instance, control of ectoparasites, such as fleas (Ctenocephalides felis and C. canis) and ticks (Rhipicephalus sanguineus) that transmit diseases to domestic animals, requires the use of some alternative insecticides to the currently used chemotoxic agents, which are harmful to animal and human health as well as to the environment (Chaves, 2020).

\section{SWOT analysis of herbal medicine}

The traditional knowledge of tribal and rural people about plant wealth with reference to human health forms the basis for the contemporary drug discovery strategies. Most of the raw material required is collected from the wild and only few medicinal plants are being cultivated on a large scale. Sustainable collection, cultivation and conservation of plant wealth are thus crucial, given that the common traditions of yesterday are in fact the popular drugs of tomorrow (Gurib-Fakim, 2006). Overexploitation and indiscrete harvesting of plants, environmental pollution, climate change, geographic or genetic loss of variants, stimulation of mutations, lack of organized cultivation of medicinal plants, failure in developing a buy-back policy, and bioprospecting by the pharmaceutical companies are some major causative factors responsible for the rarity and extinction of the medicinal plant species. Moreover, small isolated plant populations are subjected to genetic drift and inbreeding that reduce species ability to survive the environmental changes and demographic fluctuations (Gaston and Cunin, 1997; Karron, 1997). Competition with alien weedy species also disturbs the distribution of indigenous medicinal flora (Prasad et al., 2011). So, the medicinal plant species critically need to be conserved. The aspects that need immediate attention include (a) decline in species richness, (b) negligence towards plant systematics in higher education, (c) lack of agro-technology and cultivation practices for most of the MAPs, (d) little financial support for long-term research in conservation biology, (e) poor supply of herbal material due to imbalance in indigenous supply vs export, and (f) shortage of research labs with state-of-the-art facilities for quality control and assurance (Prasad et al., 2007).

On analyzing the strengths, weaknesses, opportunities and threats (SWOT) of herbal medicine, we find that its major strengths include the absence of adverse side effects, the long-lasting permanent impact on health of the users, and perhaps the cost-effectiveness, while weaknesses, if at all, are that some herbs do exhibit side effects and that the duration of treatment is relatively longer. Opportunities for herbal medicine are ceaseless because of its fastgrowing popularity even in the western world, while the orient has already been its traditional home. The threats, if any, emanate obviously from modern medicine, which offers immediate and quick relief in emergent situations and is perfectly evidence-based. So, the competition is tough and hence the advocates of herbal medicine should think how to move it ahead in the competitive world so that it captures a larger global market.

The fast-increasing use of herbal and ethno-medicine, together with the rapid decline of forests all over the globe, has made it indispensable to conserve the threatened medicinal plants. As India, Tibet, China and many African and Latin American countries are known for their traditional medicine, most of which including the Chinese medicine, and the Ayurveda and Unani in India, are based mainly on herbs (Parveen et al., in press), huge quantities of plant materials and extracts are needed for manufacturing the herbal formulations, and also for allied industries of food, nutraceuticals, cosmetics, perfumes and toiletries. Maintaining the supply of medicinal plants is a problem, as most of them are harvested from the wild. Now that the trade has attained global dimensions, there is a need to establish this trade on a sustainable basis. 
In brief, (a) conservation of the fast-dwindling wealth of medicinal plants appears to be the basic and urgent requirement to ensure a sustainable supply of raw materials; (b) proper characterization of medicinal plant species is essential to weed out adulterants or substitutes and ensure the use of genuine materials; (c) scientific authentication of various herbs used in traditional formulations under the local vernacular names is essential, because the botanical identity of many of them is still controversial; (d) proper standardization and quality control of the products under processing has to be ensured and, finally, (e) clinical evidence needs to be generated regarding the efficacy and safety of herbal drugs in use (Iqbal and Srivastava, 1997; Olorode, 2004; Patwardhan et al., 2004; Iqbal et al., 2011a).

\section{Conservation of medicinal plants}

With exploding human population and growing global economic activity associated with habitat conversion, biodiversity is bound to decline. The International Union for Conservation of Nature and Natural Resources (IUCN) Red Data book has assigned "endangered" status to 34,000 plants. Conservation of biodiversity has thus become one of the most pressing environmental issues.

In situ conservation of plant biodiversity, i.e., conservation within ecosystems and natural habitats, allows and enables the species concerned to maintain and flourish within the context of ecosystem in which they occur naturally (Olorode, 2004). During domestication outside their natural habitat, many wild plants behave differently. Their growth and survival may be at stake, or they may hardly produce the desired metabolites of therapeutic value, as was recorded in the case of Aconitum heterophyllum and Podophyllum hexandrum, the two endangered species that are endemic to the north-west Himalayas (Beigh et al., 2011). Strategies for in situ conservation, like biosphere reserves, wildlife sanctuaries, national parks and sacred groves, are therefore more successful than ex situ strategies such as gene banks, field gene banks, cryobanks and botanical gardens. The sensitivity of each species to habitat change is directly related to its adaptability or versatility; the most versatile species being the least sensitive to habitat manipulation and the vice versa (Mc Neely, 1988).

In ex situ conservation, gene banks can be built for prioritized medicinal plants on the basis of threat assessment, the ethno-medicinal, botanical and ecological surveys, intraspecific variability assessment, species recovery programs, establishment of seed centers, and networking of forest reserves with the involvement of local stakeholders. Botanical gardens help conservation biology in terms of arboriculture, dendrology, cultivar conservation and maintenance, introduction of new crop genetic resources and research in habitat restoration, etc. (Jackson and Sutherland, 2000). The first formal botanic gardens were developed in some Italian universities around the middle of the $16^{\text {th }}$ century. As per the Botanic Gardens Conservation International (BGCI) database, currently there are 1775 botanic gardens and arboreta in 148 countries of the world.

\subsection{Biotechnological assistance in plant conservation}

Mass production of selected elite varieties and conservation of endangered and threatened plant species are brought about by in vitro techniques, which help in producing true-to-type plants and establishing clone banks. In vitro protocols for fast multiplication of endangered species may be especially useful for taxa that are difficult to propagate through conventional means. These techniques may be applied to recalcitrant species, elites and clonal progenies, wherein a large number of plants can be obtained from the tissue of a single individual (Anis et al., 2014). This mode of plant propagation saves storage space and time, maintains the species for which seed preservation is difficult or inappropriate, and ensures a disease-free transport and exchange of germplasm (Natesh, 2000). Somaclonal variation (heritable genetic changes in regenerated plants) can also be caused by cell culture methods. Recent works on nuclear mechanism of organogenesis and somatic embryogenesis are especially promising (Anis et al., 2014)

Cryopreservation of plant cells and meristems, whether rapid (at $-40^{\circ} \mathrm{C}$ ) or slow (at $\mathrm{ca}<-1{ }^{\circ} \mathrm{C}$ ) obtained by using liquid nitrogen or oil emulsion, respectively, provides an important tool for a long-term storage of germplasm without genetic alteration and requires a minimum space and maintenance (Tahtamouni et al., 2015). Preservation of tissues has also been achieved at low temperatures $\left(-10\right.$ to $\left.-20^{\circ} \mathrm{C}\right)$ but without ice crystallization. Vitrification (i.e., transformation of a substance into a glass-like non-crystalline amorphous solid), simplified freezing, and encapsulation-dehydration methods are also used for storage of valuable germplasm. Vitrification procedure for cryopreserving meristems involves osmotic dehydration by short exposure of meristems to a highly concentrated mixture of cryoprotectants. Cryogenic storage at ultralow temperatures under liquid nitrogen $\left(-150\right.$ to $\left.-196^{\circ} \mathrm{C}\right)$ is the method of choice for longterm preservations (Prudente and Paiva, 2017) and is achieved either via slow cooling or vitrification. Another new technique in use is encapsulation/dehydration, which was basically developed for producing synthetic seeds (somatic embryos encapsulated in a hydro-soluble gel).

\subsection{Genetic integrity and germplasm health}

Diversity in plants is essential for development of plant characters useful for human beings and therefore it is important to expand the genetic base that may be exploited via heterosis (Melchinger, 1999). Maintenance of genetic integrity under storage is a crucial issue in germplasm conservation, because genetic erosion may occur in ex situ collections, although chances are minimized under cryogenic conditions. Genetic changes via somaclonal variation are a major obstacle in this context. Medicinal plant species are required to retain quality and quantity of the desired secondary metabolites to remain effective and hence they require a regular monitoring through the enzyme- or DNA-based diagnostic methods (Prasad et al., 2011). Pathogenic infection, particularly with viruses and viroids, is another problem of germplasm collections. Besides microscopic and bioassay methods, virus detection is done either by a serological detection of capsid protein with the enzyme-linked immunosorbent assay (ELISA) and its recent variants, or by detecting the viral nucleic acid through polymerase chain reaction (PCR) technique (Natesh, 2000).

Analysis and characterization of genetic variation is fundamental to any conservation strategy, failing which may limit the species ability to keep pace with the changing selection pressure. A whole array of molecular marker techniques is now available for addressing key problems in germplasm conservation. As the patterns of variation are still poorly understood for medicinal and aromatic plant (MAP) species, application of DNA markers must be useful 
for these taxa. This can pinpoint gaps in collections, identify highpriority genotypes for conservation and determine the optimum size for gene bank accessions (Prasad et al., 2011). Molecular markers are now routinely used in the management of genetic resources.

\section{Authentication and characterization of medicinal plants}

Since plants possess diverse medicinal properties because of having some specific active ingredients, different organs of the same plant species may be effective against different diseases, or in some cases, if one organ has a healing effect, the other may be toxic, due to the presence of different active ingredients (Ali, 2020). Use of a wrong plant, or a wrong plant part, as medicine may prove ineffective or even harmful, worsening the health condition of the user. Therefore, authentication of plant material at various stages, from harvesting of plants to the development of finished product, becomes essential (Khan, 2011; Dhiman et al., 2016). An array of taxonomic, microscopic, genomic, proteomic, chemical and molecular methods are applied to identify and authenticate the herbal drug components, as described by Chaudhary et al. (2014). Of late, combination of Diffuse Reflectance (DRIFT) and Photo-acoustic Spectroscopy (PAS) has been recommended for characterization of herbal medicine (Brangule et al., 2020).

Substitution and adulteration practices in crude drugs that grow mostly wild and are collected from their natural habitat, have rendered the standardization of medicinal plants indispensable. Moreover, plant drugs are described generally by their commercial or vernacular names rather than the botanical names. As a result, in many cases several different plant species, often belonging to different genera and even to different families, are used under one popular drug name. For instance, 5 different plant species (Canscora diffusa, Clitoria ternatea, Convolvulus microphyllus, Evolvulus alsinoides and Lavendula bipinnata) are available in the market under the name of Shankhpushpi; 6 species (Alkanna tinctoria, Anemone obtusiloba, Geraneum wallichianum, Jatropha glandulifera, Onosma echioides and Potentilla nepalensis) under the name of Ratanjot; 8 species (Anisomelis indica, Arnebia benthamii, Coccinia glauca, Elephantopus scaber, Heliotropium ophioglossum, Onosma bracteatum, Trichodesma indicum and T. zeylanicum) under the name of Gaozaban; and 8 species (Cimicifuga foetida, Dregia volubilis, Flickingeria nodosa, Gymnema sylvestris, Holostemma adakodien, Leptadenia reticulate, Sarcostemma acidum and Trema orientalis) under the name of Jiwanti, as all these species resemble morphologically to the respective drug described in the ancient literature on the basis of morphological characters (Iqbal et al., 2018). On the contrary, a single plant species is sometimes used with different drug names. Thus the botanical identity of so many 'single herbal drugs' is still controversial. It therefore becomes essential to identify these plant drugs on scientific basis so as to be able to authenticate their botanical identity and find out which of them the genuine drug is (Iqbal et al., 2011a). The best criterion to distinguish and isolate the genuine drug from pseudo-drugs may be the level of their active ingredients responsible for their therapeutic property. Of the various candidate species, the one containing the maximum amount of the ingredient concerned may be taken as the actual drug, those having relatively less amounts be regarded as substitute drugs, whereas those having the ingredient in traces, or lacking it altogether, must be rejected once for all.
However, it should be kept in mind that the amount of active ingredients may vary with the habitat, depending on soil characteristics and agro-climatic conditions of the region. Artemisinin content of Artemisia annua, for instance, has been found to vary widely (from almost nil to $0.5 \%$ ) in plants growing at different geographical locations. The impact of the habitat environment on medicinal properties of plants growing there was duly appreciated by the ancient physicians, so much so that they attached the name of the place of origin to the vernacular name of the drug, as we see in the case of several Unani single drugs, such as Ajwayin Khurasani (Hyoscyamus niger), which comes basically from Khorasan (Central Asia, eastern part of Iran, Afghanistan); Kundur Romi (Pistacia lentiscus), which came from Rome and the Greek island of Chios; Rewand Chini (Rheum emodi), which originated and is cultivated in China; Salab Misri (Orchis mascula), which originated on the Egyptian territories; Samaghe Arabi (Althea officinalis) which originated in Arab world, Eastern Mediterranean region; Sana makki (Cassia angustifolia), which came from the Arab land; and Tamar Hindi (Tamarindus indica), which is grown mainly in the Indian sub-continent.

Moreover, even within the same individual of a plant species, organographic distribution of active ingredients may vary to a great extent with its amount being different in root, stem, leaves, flowers, fruits and seeds etc. (Iqbal et al., 2011a). The amounts of bioactive compound(s) may also vary with the stage of plant development, with nutritional status of the plant, and with the local environmental conditions. Variations in the contents of artemisinin (in Artemisia annua), peruvoside and neriifolian (in Thevetia neriifolia), vincristin and vinblastin (in Catharanthus roseus), hyoscyamine (in Datura innoxia), xanthotoxin (in Ammi majus and Podophyllum hexandrum), and sennoside (in Cassia angustifolia), among others, substantiate these facts (Iqbal et al., 2011a, 2018; Majid et al., 2013). Certain plants, including the medicinal plants, have a tendency of accumulating large amounts of heavy metals. These plant species may be good for bio-indication and remediation of metal-polluted sites, but their use as a medicine, when collected from polluted sites, may be harmful to the user (Alirzayeva et al., 2011). Above all, environmental degradation may affect not only the quantity of active ingredients but, sometimes, even their composition (Iqbal, 2013). For instance, the relative proportions of the component fatty acids in some seed oils known for therapeutic uses have been found to change under the effect of environmental pollution (Iqbal et al., 2011b; Qureshi et al., 2013). This situation, under extreme conditions, is likely to alter the degree of efficacy of the oil or other such compounds. Thus, the environmental degradation has a far-reaching influence on the therapeutic potential of medicinal plants (Iqbal, 2013).

Characterization of single herbal drugs is done normally on the basis of a prescribed set of their inherent traits or characteristic features, constant parameters and definite qualitative and quantitative values, which usually include (a) morphological and anatomical study, (b) powder analysis, (c) total ash content, (d) acid-insoluble ash, (e) alcohol-soluble extractive, (f) water-soluble extractive, (g) loss on drying, and (h) thin layer chromatography. Of late, DNA finger-printing and other molecular parameters have been included in the list of characters to be analyzed. Parveen et al. (2020) have categorized some 244 single phyto-drugs included in 
the Unani Pharmacopoeia of India (Part I), on the basis of plant parts (stem, leaves, spadix, aril, flowers, fruits, seeds, stamens, rhizomes, roots, bulbs, bark, wood, whole plant, dried galls, gums/ exudates) used as medicine, and provided information on their trade name, botanical name, main chemical constituents and major healing properties, and also about the formulations in which these drugs are used.

\section{Quality control of herbal products}

All living or non-living things in the world experience aging effect, undergo wear and tear due to environmental impacts, and are subject to decay/death. Drugs are no exception. Quality and stability of compound formulations have long been a neglected aspect in the trade of herbal medicine. Good manufacturing practices (GMP) need to be applied to the production of compound herbal drugs. Stability of drug substances and drug products is a critical feature in the process of drug development, based on which a shelf life for pharmaceutical products is established and storage conditions are recommended. Stability testing is done to explore how the quality of herbal products varies with time under the influence of environmental factors, and to establish a recommended storage condition and shelflife. Stability testing of herbal products is, however, a challenging task, because the entire herb or the herbal product is regarded as an active substance, irrespective of its constituents with defined therapeutic activity (Noorul-Basar et al., 2013).

Jalinoos (Galen: AD 130-201) was the first to mention in his book 'Kitabul Murakkabaat' that all powders retain their potency at the most for two months, Hab and Qurs (pills and tablets) have a longer shelf-life than Sufoof (powder), whereas Sharbat (syrup) may remain in good form for about one year (Geelani, 1995). Joel Davis of the US Food and Drug Administration (FDA) proposed in 1991 what is now known as the Joel Davis Rule, i.e., 3-month duration at $40{ }^{\circ} \mathrm{C}$ temperature or $75 \%$ relative humidity is roughly equivalent to 24 months at room temperature $\left(25^{\circ} \mathrm{C}\right)$ (Davis, 1991). Prior to this, the historical 'rule of thumb' was that 5 weeks of storage at $42{ }^{\circ} \mathrm{C}$ was regarded as equivalent to two years of storage at room temperature. This rule was derived from the work done in 1948 on stability of vitamin A (Carstensen and Rhodes, 2000). There have been various interesting claims regarding the extraordinarily long shelf-life of some herbal formulations, like Triyaaq, Kushta/Bhasma and certain specific oils (CCRUM, 2006; Noorul-Basar et al., 2013; Rani et al., 2015). The Government of India has modified the Drugs and Cosmetics Rules (1945), by adding relevant explanation to rule $161 \mathrm{~A}$, and clarified that even the Ayurveda, Unani and Siddha medicines shall declare their shelf-life and display the expiry date, beyond which the medicine should not come into circulation. Gazette notification to this effect was made on October 15, 2009.

Product stability is affected by physical as well as chemical degradation of the product. Higher temperatures are known to have devastating effect on physical stability of preparations (Pandey et al., 2011). Solid state reactions are relatively slow and the degradation rate of dry solids is usually characterized by the first order kinetics or a sigmoid curve. Therefore, solid drugs having a low melting-point temperatures should not be combined with such other chemicals that may give rise to a eutectic mixture. Of late, microbial status of drug-delivery system has also been taken into consideration (Walter, 1994). Several chemical reactions (mostly oxidation and hydrolysis) can cause degradation of drug substances and excipients. Exposure to high temperature, light, humidity, oxygen, and carbon dioxide may reduce drug stability. Other major factors affecting the drug stability include particle size (especially in emulsions and suspensions), $\mathrm{pH}$, solvent system composition (percentage of free water and the overall polarity), compatibility of anions and cations, specific chemical additives and molecular binding, and diffusion of drugs and excipients. In addition to hydrolysis and oxidation, other reactions that destroy the therapeutic efficacy of drugs, include epimerization, decarboxylation, dehydration and photochemical decomposition (Walter, 1994; USP-NF, 2018). All these reactions are affected most by temperature.

In the case of herbal medicines or extracts, highly acidic $\mathrm{pH}$ of stomach may possibly destroy several compounds, or liver may metabolize them before they reach the blood, thus preventing the required amount of medicine from reaching the blood and nullifying the therapeutic impact of the drug dose taken. Nanotechnology is now available to improve the drug-delivery process. Therefore, by controlling the release kinetics, or protecting the active agents, it is now possible to enhance the therapeutic index of traditional medicines via specific drug targeting to a given tissue, cells or intracellular compartments (Parveen et al., 2014). The probable intervention of stomach and liver can thus be bypassed. Numerous nano forms, like polymeric nanoparticles, nanocrystals, nanoemulsions, nanocapsules, phytosomes, liposomes, ethosomes, niosomes, transferosomes and microspheres are now prepared using the herbal extracts. These novel formulations have great advantages over the traditional ones such as improved solubility and bioavailability, protection from toxicity, enhanced pharmacological activity, increased stability, sustained delivery and protection from physical and chemical degradation (Parveen et al., 2011, 2014, 2019).

\section{Efficacy and safety of herbal medicine}

Efficacy and safety of traditional herbal drugs stand established because of their continued usage for thousands of years, but extensive research needs to be undertaken in order to allay public concern regarding their quality control and clinical validation. The growing and widespread use of herbal medicines in the form of complementary and alternative medicine (CAM) is bound to increase the pressure for clinical evidence. Application of reverse pharmacology is recommended in the case of traditional medicines. Reverse Pharmacology integrates the documented experiential hits into leads by transdisciplinary investigative studies, which then develop into drug candidates through experimental and clinical research. It particularly suits countries like India that have pluralistic healthcare systems and may develop a robust clinical and laboratory documentation of novel pharmacodynamic effects through intersystem collaborative teamwork (Patwardhan et al., 2004; Parveen et al., in press). Observational therapeutics is a prelude to the path of reverse pharmacology for development of new natural drugs.

Although herbal medicines are safe and free from adverse side effects in general, yet exceptions do exist. Many herbs exhibit side effects as well as interaction (positive or negative) with other drugs. A three-volume series on 'Adverse Effects of Herbal Drugs' was published by Springer in the 1990s (Keller et al., 1992, 1993, 1997). Several herbs or herbal products can interact with food, allopathic 
drugs, or pharmaceuticals, but unfortunately, information on this aspect is still scanty, and reports on herb-drug interaction are often sketchy, lacking laboratory analysis. Kamil (2014) described the medicinal uses as well as interactive effects with allopathic medicine of 28 herbs, viz., Alfalfa (Medicago sativa), Aloe (Aloe vera), Agrimony (Agrimonia eupatoria), Andrographis (Andrographis paniculata) Angelica (Angelica officinalis), Arnica (Arnica montana), Asafoetida (Ferula asafetida), Betel nut (Areca catechu) Black cohosh (Cimicifuga racemosa), Bladder wrack (Fucus vesiculosus), Borage (Borago officinalis), Cascara (Rhamnus purshiana), Comfrey (Symphytum officinale), Dandalion (Taraxacum officinale), Danshen (Salvia miltiorrhiza), Echinacea (Echinacea purpurea), Ephedra (Ephedra sinica), Feverfew (Tanacetum parthenium), Garlic (Allium sativum), Germander (Teucrium chamaedrys), Ginger (Zingiber officinale), Ginko (Ginkgo biloba), Ginseng (Panax ginseng), Guar gum (Cyamopsis tetragonolobus), Kava-kava (Piper methysticum), Liquorice (Glycyrrhiza glabra), Senna (Cassia angustifolia) and St. John's wort (Hypericum perforatum).

Given the above, a careful blend of traditional herbal medicine and evidence-based clinical disease management can ensure far better health care opportunities to people with natural herbal treatment. Figure 1 exhibits the steps required to be taken to develop formulations based on traditional knowledge, keeping in view expectations of the modern world.

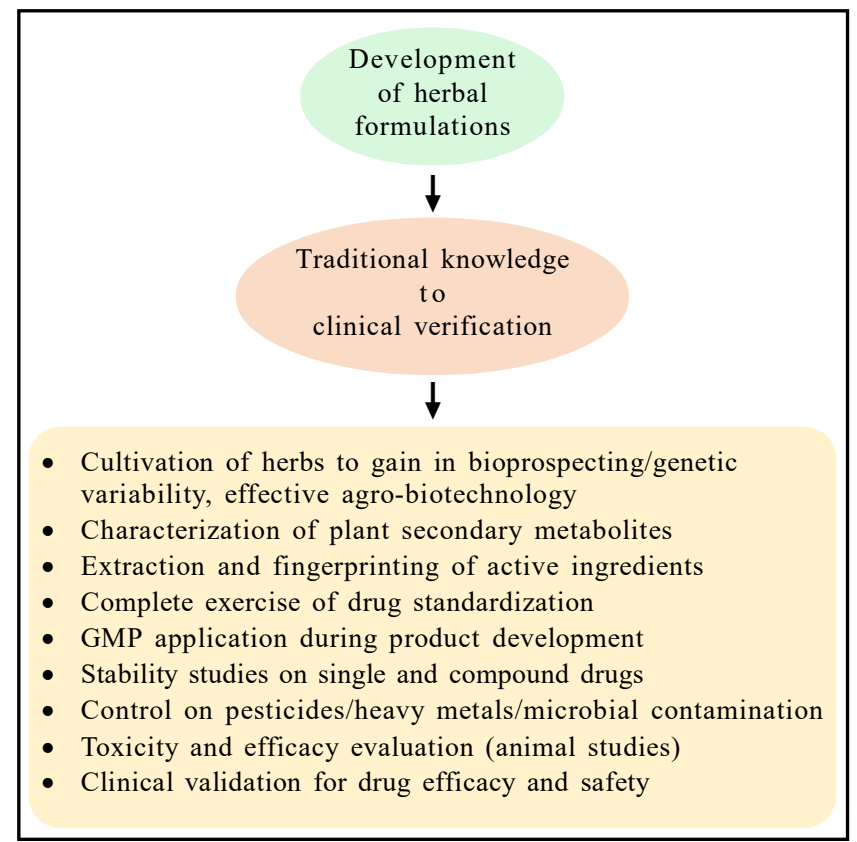

Figure 1: Steps required to be taken to develop formulations of herbal medicine based on the age-old traditional knowledge.

\section{Status and scope of herbal medicine in India}

Approximately 8000 plant species are used as medicinal plants, constituting about $50 \%$ of the total number of higher flowering plant species in India. They include a number of spices and edible plants which are now regarded as an important source of drugs (Alam, 2019; Ansari and Ahmad, 2019; Sekeroglu, 2019). India is sufficiently strong on herbal medicine because two of its traditional systems of medicine (Ayurveda and Unani) are almost solely dependent, while the third one (Siddha) is partially dependent, on herbal materials (Parveen et al., in press). Herbal formulations have evolved in India through a long process of trial and error, empirical reasoning and also experimentation. However, rationalization of traditional systems of medicine is now indispensable in order to meet international standards for specification of crude drugs as well as the processed products. Information on the chemical profile of the whole plant and the different plant parts, vis-à-vis plant age and habitat environment, is important in standardizing the herbal products (Iqbal et al., 2011a). Based on these data, and keeping in view the type of bio-molecules and their potency and synergism, re-formulation of classical medicines can create new openings for herbal therapeutic products. Study of bio-molecules in hitherto unexploited plants and the development of products for use not only as drugs but also as nutraceuticals or functional foods in preventive health care, such as weight regulation, stress management and immunity enhancement, may further broaden the scope of traditional systems. A new online database - Indian Medicinal Plants, Phytochemistry and Therapeutics (IMPPAT) - has identified 960 phytochemicals present in Indian herbs that can potentially be developed into drugs. Produced by the Institute of Mathematical Sciences (IMSc), Chennai, this manually curated free-to-access database, combining information from 50 books on traditional Indian medicine with catalogues from previous databases and scientific papers, carries information on 1742 Indian medicinal plants, 9596 phytochemicals, and 1124 therapeutic uses, spanning over 27,074 plant-phytochemical associations and 11,514 plant-therapeuticuse links (Mohanraj et al., 2018).

About $65 \%$ of the Indians make use of traditional medicine for their health care needs. More than 1.5 million traditional practitioners use herbal medicine for preventive, promotional, and curative purposes (Wakdikar, 2004). The Indian systems of medicine are not based on mere folklores or traditional practices but have their well-defined basic axioms, leading to a logical and systematic structure of pathogenesis and diagnosis (Vaidya and Devasagayam 2007). In the year 2014, the Government of India created a fullfledged Ministry of AYUSH (Ayurveda, Yoga and Naturopathy, Unani, Siddha and Homeopathy), which regulates different independent Councils involved in planning and supervising the education, research and promotion of their respective medical systems through collaborative programs with educational and research institutions and different governmental and non-governmental agencies. Table 1 provides a glimpse of institutions that are conducting significant research on varied aspects of herbal medicine.

Indian forests are rich in vegetation of medicinal utility. The panorama of Indian forests extends from evergreen tropical rain forests in the Andaman and Nicobar Islands to dry alpine scrubs in the Himalayan range and comprises a variety of vegetation including the subtropical, semi-evergreen, deciduous, broad-leaved as well as coniferous forests. India occupies $2.4 \%$ of the total geographical area of the world, but accounts for $8 \%$ of the global biodiversity, including nearly 49,000 plant species of which 5,150 species are endemic (Singh, 2007; NBA, 2012). More than 3,500 plant species of a total of 49,000 exhibit medicinal value (Singh, 2007). It is estimated that more than 600 medicinal plant products, and over 100 mineral-plus-animal products are commonly used in traditional 
Ayurvedic preparations, and more or less the same applies to Unani formulations. The list of potent phytochemicals from Indian medicinal plants is now pretty long.

The turnover of the Indian herbal industry is said to be more than Rs 80 billion per year. Seventy percent of the export from herbal sector consists of raw materials, while $30 \%$ relates to finished products, including herbal extracts. It has been estimated that about 880 medicinal plants are involved in Indian trade (Kumar and Janagam, 2011). European countries hold the greatest share of the total herbal market (45\%), followed by the Association of SouthEast Asian Nations (ASEAN) countries (19\%), Japan (16\%), and North America (11\%) (Agarwal et al., 2013). Although India stands next to the People's Republic of China in the medicinal-plant exports, the difference between the two is vast. When the China's share in the global export was around $28 \%$, India's share was only $8.13 \%$ (Sen et al., 2011).

When the quality of herbal products is questioned, standardization of raw material emerges as a major issue. As per the estimation of National Medicinal Plants Board, India, about $77 \%$ of medicinal plants used in the country come from forests and wastelands. They may be easily contaminated during their growth, collection, and/or processing via adulteration, substitution or heavy-metal contamination, and this obviously affects the quality of the finished products (Sahoo et al., 2010). A study has revealed that out of 260 Asian patented medicines, about $25 \%$ contained heavy metals beyond the permitted limit, while inclusion of undeclared drugs to increase the therapeutic efficacy was also detected in $7 \%$ of those medicines (Sen and Chakraborty, 2015).

One more aspect that deserves attention of Indian herbalists relates to IPR (intellectual property right), the legally enforceable rights to individuals or corporate bodies to have a monopolistic ownership or control over the things that emanate from exercise of human brain such as thoughts, ideas and information regarding new inventions, innovations and processes. This right was reportedly recognized first in Italy in the $15^{\text {th }}$ century. However, the exercise of patenting right got a formal shape after the Paris Convention (1853). The promoters of traditional herbal drugs should go in for patenting their products, keeping due share in profits of the local rural/tribal people, as per articles $8(\mathrm{j})$ and 10 (c) of CBD (the UNO's Convention on Biodiversity), if the product is based on traditional knowledge obtained from such people (Pushpangadan et al., 2014). Further, biopiracy also contaminates the herbal trade. A survey conducted by a TKDL (Traditional Knowledge Digital Library) task force, based on 4,896 references, revealed that 90 medicinal plants of Indian origin were listed in the US Patent and Trademark Office Database, and about $80 \%$ of references were related to seven medicinal plants of Indian origin, viz., aloe (Aloe vera), nut grass (Cyperus rotundus), tobacco (Nicotiana tabacum), carrot (Daucus carota), linseed (Linum usitatissimum), limon (Citrus jambiri) and muskmelon (Cucumis melo). The task force also noted that 360 of 762 patents were based on medicinal plants that could be classified as 'traditional' (Sen and Chakraborty, 2014).

The Materia Medica of India encompasses 2,000 drugs of natural origin (derived from traditional systems of medicine) along with their therapeutic uses. Only 400 of these are from mineral and animal sources, whereas the rest come from plant sources (Mukherjee et al., 2007). The TKDL contains information on 500 Ayurveda, 500 Unani, and 200 Siddha formulations and also on 291 plants being used as ingredients in different traditional formulations (Sen and Chakraborty, 2014). The bulk of literature on Ayurveda occurs in Sanskrit, Hindi and some regional languages, whereas Unani literature is found mainly in Arabic, Persian and Urdu, and hence both are often inaccessible to other language groups. However, numerous research papers and dozens of books/monographs on traditional herbal medicine in India have now started appearing in English every year. Some selected books published in the recent past are enumerated in Table 2.

A survey conducted on regulation and commercialization of Indian herbal drugs indicated that poor standardization and quality control of raw materials and finished products in the Indian herbal drug industry, insufficient regulatory guidelines concerning GMP (good manufacturing practices), non-application of GACP (good agricultural and collection practices), a weak implementation of the DCA (Drugs and Cosmetics Act)-1940, and the diverse regulatory requirements in different foreign countries are the major hurdles in trade of the Indian herbal industry (Sahoo and Manchikanti, 2013). Companies producing herbal drugs all over the world, traditionally import most of their raw plant material from China, India, and the Eastern European countries. With the industry growing mature, the companies have instituted new quality control measures that include testing plants for active compounds, purity and bacterial contamination. As per the Indian Drugs and Cosmetics Act (1940), no safety and efficacy studies are required for marketing approval, but rules are more stringent in some other countries. Given this, most of the Indian herbal products are marketed in the USA as dietary supplements, as the US Dietary Supplement Health and Education Act (1994) does not require submission of any safety or efficacy data for marketing approval (Sahoo and Manchikanti, 2013).

Insufficient regulatory guidelines for production process constitute a major factor affecting the quality of herbal medicinal products. Unfortunately, only few companies in the Indian herbal industry are GMP compliant, even though GMP compliance is compulsory (since 2006) as per the Schedule T of the DCA (1940). In India, most of the traditional medicinal products are available as 'over the counter' drugs and their market is often influenced by advertisement and customer's preference, as against the 'prescription medicines' that are controlled largely by physicians (Sahoo and Manchikanti, 2013). Generation of evidence-based data on safety and efficacy of herbal products is also essential for gaining the ground firmly both in the domestic and the export market (Parveen et al., in press). India must manage a well-planned plant cultivation, postharvest technology and processing of plants, and ensure a high-tech manufacturing, quality control, research and extension, easy patenting, and a wise marketing strategy for plant products. Regulatory harmonization among countries is needed for an effective global commercialization. On the whole, traditional herbal medicines that have gained enough ground in China and the Indian sub-continent deserve special and immediate attention, as they have to reign over the entire globe during the days to follow. 
Table 1: Some major Indian institutions involved in research and publication on herbal medicine

\begin{tabular}{|c|c|c|}
\hline Institution & $\begin{array}{l}\text { City with } \\
\text { Postal Code }\end{array}$ & E-mail \\
\hline Aligarh Muslim University (AMU) & Aligarh 202002 & vcamu@amu.ac.in \\
\hline Ayurvedic and Unani Tibbia College & New Delhi 110005 & pmstibbiacollege@rediffmail.com \\
\hline Banaras Hindu University (BHU) & Varanasi 221005 & $\begin{array}{l}\text { directorims@satyam.net.in } \\
\text { vc@bhu.ac.in }\end{array}$ \\
\hline Botanical Survey of India (BSI) & Kolkata 700064 & bsi_headquarter@rediffmail.com \\
\hline Central Council for Research in Ayurveda and Siddha (CCRAS) & New Delhi 110058 & dg-ccras@nic.in \\
\hline Central Council for Research in Unani Medicine (CCRUM) & New Delhi 110058 & unanimedicine@gmail.com \\
\hline Central Drug Research Institute (CDRI) & Lucknow 226031 & director@cdri.res.in \\
\hline Central Institute for Medicinal and Aromatic Plants (CIMAP) & Lucknow 226015 & director@cimap.res.in \\
\hline Dr Hari Singh Gour University (Sagar University) & Sagar 470003 & registrardhsgsu@rediffmail.com \\
\hline Foundation for Revitalization of Local Health Traditionas (FRHLT) & Bengaluru 560106 & frlht@envis.nic.in \\
\hline Gujarat Ayurved University & Jamnagar 361008 & $\begin{array}{l}\text { info@ayurvedauniversity.com } \\
\text { registrar@ayurveduniversity.com }\end{array}$ \\
\hline Institute of Bioresources and Sustainable Development (IBSD) & Imphal 795001 & director.ibsd@nic.in \\
\hline Indian Council for Medical Research (ICMR) & New Delhi 110029 & icmrhqds@sansad.nic.in \\
\hline Indian Institute of Integrative Medicine (IIIM) & Jammu1 80001 & director@iiim.res.in \\
\hline Interdisciplinary School of Health Sciences (ISHS) & Pune 411007 & shs@unipune.ernet.in \\
\hline International Association for the Study of Traditional Asian Medicine (IASTAM), India & Mumbai 400012 & iastam.india@gmail.com \\
\hline Jadavpur University & Kolkata 700032 & registrar@jadavpuruniversity.in \\
\hline Jamia Hamdard (Deemed University) & New Delhi 110062 & registrar@jamiahamdard.ac.in \\
\hline Lallubhai Motilal (LM) College of Pharmacy & Ahmedabad 380009 & admin@1mcp.ac.in \\
\hline National Botanical Research Institute (NBRI) & Lucknow 226001 & director@nbri.res.in \\
\hline National Bureau of Plant Genetic Resources (NBPGR) & New Delhi 110012 & director.nbpgr@icar.gov.in \\
\hline National Chemical Laboratory (NCL) & Pune 411008 & director@ncl.res.in \\
\hline National Institute of Ayurveda (NIA) & Jaipur 302002 & nia-rj@nic.in \\
\hline National Institute of Pharmaceutical Education and Research (NIPER) & Mohali 160062 & registrar@niper.ac.in \\
\hline National Institute of Pharmaceutical Education and Research (NIPER) & Guwahati 781101 & registrar@niperguwahati.ac.in \\
\hline National Institute of Unani Medicine (NIUM) & Bengaluru 560091 & niumhospita12004@gmail.com \\
\hline National Medicinal Plant Board (NMPB) & New Delhi 110001 & info-nmpb@nic.in \\
\hline National Institute of Science Communication and Information Resources (NISCAIR) & New Delhi 110012 & director@niscair.res.in \\
\hline National Research Institute of Unani Medicine for Skin Disorders (NRIUMSD) & Hyderabad 500038 & criumhyderabad@gmail.com \\
\hline Pharmaceutical Education Research Development (PERD) Centre & Ahmedabad 380054 & perd@perdcentre.com \\
\hline Panjab University & Chandigarh 160014 & regr@pu.ac.in \\
\hline RT Maharaj Nagpur University & Nagpur 440001 & registrar@nagpuruniversity.nic.in \\
\hline National Institute of Traditional Medicine (NITM) & Belgavi 590010 & director.nitm.bg@gmail.com \\
\hline SD-Advanced Centre for Ayurveda Research Training and Services (SD-ACARTS) & Mumbai 400008 & deannt@vsnl.net \\
\hline Tropical Botanical Garden and Research Institute (TBGRI) & $\begin{array}{l}\text { Thiruvananthapuram } \\
695562\end{array}$ & director_tbgri@rediffmail.com \\
\hline University of Kashmir & Srinagar 190006 & registrar@kashmiruniversity.ac.in \\
\hline
\end{tabular}


Table 2: Some selected books on Indian herbal medicine from those published during the last two decades*

\begin{tabular}{|c|c|c|}
\hline Book Title & Year & Author/Editor \\
\hline Adulteration in Herbal Drugs: A Burning Issue & 2019 & Shaheen, S. et al. \\
\hline Agrotecnniques of Medicinal Plants & 2018 & Sharma, R. \\
\hline Artemisia апnиа - Pharmacology and Biotechnology & 2014 & Aftab, T. et al. \\
\hline Artemisia annua: Prospects, Applications and Therapeutic Uses. & 2018 & Aftab, T. et al. \\
\hline Ayurveda at the Turning Point & 2018 & Katiyar, C.K. and Khare, C.P. \\
\hline Ayurvedic Medicinal Plants of India & 2011 & Bhutya, R.K. \\
\hline Bioactive Natural Products in Drug Discovery & 2020 & Singh, J. et al. \\
\hline Biotechnology for Medicinal Plants: Micropropagation and Improvement & 2013 & Chandra, S. et al. \\
\hline Catharanthus roseus: Current Research and Future Prospects & 2017 & Naeem, M. et al. \\
\hline Chinese and Indian Medicine Today & 2017 & Islam, M.N. \\
\hline Clinically Useful Herbal Drugs & 2005 & Agrawal, S.S. et al. \\
\hline Colour Atlas of Medicinal Plants & 2018 & Bhutya, R.K. \\
\hline Cultivation of Medicinal and Aromatic Crops & 2004 & Farooqui, A.A. and Sreeramu, B.S. \\
\hline Current Trends in Medicinal Botany & 2014 & Iqbal, M. and Ahmad, A. \\
\hline Direct Uses of Medicinal Plants and their Identification & 2008 & Vardhana, R. \\
\hline Drug Discovery and Development: Traditional Medicine and Ethnopharmacology & 2007 & Patwardhan, B. \\
\hline Encyclopaedia of World Medicinal Plants & 2019 & Pullaiah, T. \\
\hline Ethnobotany and Medicinal Plants of India and Nepal & 2003 & Singh, V. \\
\hline Ethnobotany for Human Welfare & 2018 & Baruah, A. \\
\hline Ethnomedicinal Plants: A Biodiversity Treasure & 2018 & Mohan, V.R. et al. \\
\hline Ethnomedicinal Plants of India & 2007 & Trivedi, P.C. \\
\hline Ethnomedicinal Plant Use and Practice in Traditional Medicine & 2020 & Akash, et al. \\
\hline Ethnomedicine and Human Welfare & 2004-07 & Khan, I.A. and Khanum, A. \\
\hline Evidence-Based Validation of Herbal Medicine & 2015 & Mukherjee, P.K. \\
\hline GMP for Botanicals - Regulatory and Quality Issues on Phytomedicine & 2003 & Verpoorte, R. and Mukharjee, P.K. \\
\hline Greco Arab and Islamic Herbal Medicine: Traditional System, Ethics, Safety, Efficacy, and Regulatory Issues & 2011 & Saad, B. and Said, O. \\
\hline $\begin{array}{l}\text { Handbook of } 200 \text { Medicinal Plants: A Comprehensive Review of their Traditional Medical Uses } \\
\text { and Scientific Justifications }\end{array}$ & 2020 & Akbar, S. \\
\hline Handbook of Indian Medicinal Plants & 2019 & Joshi, M.C. \\
\hline Handbook on Unani Medicine with Formulae, Processes, Uses and Analysis & 2004 & N.I.I.R. \\
\hline Herbal Drugs and Biotechnology & 2004 & Trivedi, P.C. \\
\hline Herbal Drugs and Fingerprints & 2012 & Joshi, D.D. \\
\hline Herbal Drugs: Ethnomedicine to Modern Medicine & 2009 & Ramawat, K.G. \\
\hline Herbal Medicine for Human Diseases & $2005-08$ & Khan, I.A. and Khanum, A. \\
\hline Herbal Medicine in India: Indigenous Knowledge, Practice, Innovation and its Value. & 2020 & Sen, S.and Chakraborty, R. \\
\hline Herbal Medicine: Traditional Practices & 2006 & Trivedi, P.C, \\
\hline $\begin{array}{l}\text { Herbal Supplements: Efficacy, Toxicity, Interactions with Western Drugs, and Effects on } \\
\text { Clinical Laboratory Tests }\end{array}$ & 2010 & Dasgupta, A. and Hammett-Stabler, C.A. \\
\hline Himalayan Phytochemicals & 2018 & Jan, S. and Abbas, N. \\
\hline Indian Folkmedicine and Other Plant-based Products & 2007 & Singh, V. \\
\hline Indian Herbal Drug Microscopy & 2014 & Gaurav, S.S. and Gaurav, N.S. \\
\hline Indian Herbal Medicines & 2004 & Khare, C. \\
\hline Indian Herbal Pharmacopoeia & 2002 & I.D.M.A. \\
\hline Indian Herbal Remedies: Rational Western Therapy, Ayurvedic and other Traditional Usage, Botany & 2011 & Khare, C.P. \\
\hline Indian Medicinal Plants: An illustrated Dictionary & 2007 & Khare, C.P. \\
\hline Licorice: From Botany to Phytochemistry & 2017 & Öztürk, M. et al. \\
\hline Medicinal and Aromatic Plants: Expanding their Horizons through Omics & 2020 & Aftab, T. and Hakeem, K.R. \\
\hline
\end{tabular}




\begin{tabular}{|c|c|c|}
\hline Book Title & Year & Author/Editor \\
\hline Medicinal and Poisonous Plants of India & 2017 & Bhoopathi, C.A. \\
\hline Medicinal Plants in Changing Environment & 2011 & Ahmad, A. et al. \\
\hline Medicinal Plants: Holistic Approaches & 2011 & Zawar, S.N. \\
\hline Medicinal Plants: Traditional Knowledge & 2006 & Trivedi, P.C. \\
\hline Medicobotany of Andaman and Nicobar Islands: Recent Study & 2017 & Dhiman, K.S. \\
\hline Nanomedicine for Bioactives: Healthcare Applications & 2020 & Rahman, M. et al. \\
\hline National Formulary of Unani Medicine & 2006 & C.C.R.U.M. \\
\hline Natural Bioactive Products in Sustainable Agriculture & 2020 & Singh, J. and Yadav, A.N. \\
\hline New Age Herbals: Resource, Quality and Pharmacognosy & 2018 & Singh, B. and Peter, K.V. \\
\hline Oral Health and Herbal Medicine & 2019 & Hakeem, K.R. et al. \\
\hline Pharmacognosy: An Indian Perspective & 2013 & Mangathayaru, K. \\
\hline Phytochemical Techniques & 2006 & Raaman, N. \\
\hline Plants and Human Health: Ethnobotany and Physiology & 2018 & Öztürk, M. and Hakeem, K.R. \\
\hline Plants and Human Health:Phytochemistry and Molecular Biology & 2019 & Öztürk, M. and Hakeem, K.R. \\
\hline Plants and Human Health:Pharmacology and Theraputics & 2019 & Öztürk, M. and Hakeem, K.R. \\
\hline Plants in Human Health and Nutrition Policy & 2003 & Simopoulos, A.P. and Gopalan, C. \\
\hline Quality Control and Evaluation of Herbal Drugs & 2019 & Mukharjee, P.K. \\
\hline Refiguring Unani Tibb: Plural Healing in Late Colonial India & 2007 & Attewell, G.N.A. \\
\hline Role of Biotechnology in Medicinal and Aromatic Plants & 2009 & Khan, I.A. and Khanum, A. \\
\hline Standardization of Botanicals. Testing and Extraction Methods of Medicinal Herbs & 2004 & Rajpal, V. \\
\hline Scientific Explorations of Adhatoda vasica & 2020 & Ali, M. and Hakeem, K.R. \\
\hline The Ayurvedic Pharmacopoeia of India: I. Single Drugs & 2016 & P.C.I.M.H. \\
\hline The Ayurvedic Pharmacopoeia of India: II. Formulations & 2017 & P.C.I.M.H. \\
\hline The Unani Pharmacopoeia of India I. Single Drugs & 2009 & P.C.I.M.H. \\
\hline The Unani Pharmacopoeia of India: II. Formulations & 2019 & P.C.I.M.H. \\
\hline The Herbs of Ayurveda & 2005 & Seth, A. \\
\hline Traditional and Folk Herbal Medicine & 2014 & Gupta, V.K. \\
\hline Traditional Medicine in Asia & 2002 & Chaudhary. R. and Rafei, U.M. \\
\hline Traditional Systems of Medicine & 2006 & Abdin, M.Z. and Abrol, Y.P. \\
\hline Unani Medicine in the Making: Practices and Representations in $21^{\text {st }}$ Century India & 2020 & Schmidt-Stiedenroth, K. \\
\hline Wild Medicinal Plants & 2018 & Singh, M.P. \\
\hline World Healing Plants for Tomorrow & 2018 & Khare, C.P. \\
\hline
\end{tabular}

*Complete reference included in the list of references

\section{Conclusion}

Herbal medicine is increasingly becoming the choice of masses because it normally has no adverse side effects, leaves a long-lasting curative impact on human health and is often cost-effective, although the duration of treatment may be a little longer. It can conveniently rub the shoulder with modern medicine, if data on its clinical validation are gathered in scientific manner.

Most of the raw materials (plants with medicinal utility) to be used for manufacturing the herbal health products are collected from forests, where these plants grow wild as the natural vegetation. In order to be sure about the authenticity of the materials used, manufacturers of herbal medicines should manage formal cultivation of the required medicinal herbs. They may also sign buy-back agreements with farmers, provide authenticated seeds and suitable agro-technology to them with some advance payment, and then buy the whole crop after harvest. In the absence of such provisions, herbal industry must ensure an authentic identification of herbs collected from forests, and get them characterized possibly based on the content of their active ingredients, before using them for product development. Side by side, the Government agencies concerned should plan for in situ as well as ex situ conservation programs for the identified herbs of medicinal utility, using modern biotechnological means.

Good manufacturing practices (GMP) need to be adopted during the process of drug manufacturing in order to assure the quality and stability of the products. Further, to satisfy the modern mind, clinical data should also be generated regarding the efficacy and safety of traditional herbal drugs, despite the fact that these aspects already stand established through the continued experience of their therapeutic outcome for thousands of years. Future of traditional herbal medicine in India is safe and promising, as the two major 
Indian systems of medicine, i.e., Ayurveda and Unani, are almost solely based on herbal preparations. Also, there is a provision of formal education and training in both these disciplines, leading to award of graduate and post-graduate degrees.

\section{Conflict of interest}

The authors declare that there are no conflicts of interest relevant to this article.

\section{References}

Abdin, M.Z. and Abrol, Y.P. (2006). Traditional systems of medicine. Narosa Publishing House, New Delhi, India.

Aftab, T.; Ferreira, J.F.S.; Khan, M.A. and Naeem, M. (2014). Artemisia annua - Pharmacology and biotechnology. Springer, Germany.

Aftab, T.; Naeem, M. and Khan, M.A. (2018). Artemisia annua: Prospects, applications and therapeutic uses. CRC Press, Taylor and Francis, USA.

Aftab, T. and Hakeem, K.R. (2020). Medicinal and aromatic plants Expanding their horizons through omics. Academic Press, Elsevier, USA.

Agarwal, P.; Alok, S.; Fatima, A. and Verma, A. (2013). Current scenario of herbal technology worldwide: An overview. Int. J. Pharm. Sci. Res., 4:4105-4117.

Aghaei, K. and Komatsu, S. (2013). Crop and medicinal plants proteomics in response to salt stress. Front. Plant Sci., 4:8. (DOI: 10.3389/ fpls.2013.00008).

Agrawal, S.S.; Tamrakar, B.P. and Paridhavi, M. (2005). Clinically useful herbal drugs. Ahuja Book Publishers, New Delhi, India.

Ahmad, A.; Siddiqi, T.O. and Iqbal, M. (2011). Medicinal plants in changing environment. Capital Publishing Company, New Delhi, India.

Ahmad, W.; Ali, A.; Ali, M.; Mir, S.R.; Zaidi, S.M.A. and Ahmad, S. (2017). New fatty acid and aromatic monoterpenic esters from the leaves of Didymocarpus pedicellata $\mathrm{R}$. Br. Indian Drugs, 54:28-32.

Akash; Navneet and Bhandari, B.S. (2020). Ethnomedicinal plant use and practice in traditional medicine. IGI Global, Hershey, USA.

Akbar, S. (2020). Handbook of 200 medicinal plants: A comprehensive review of their traditional medical uses and scientific justifications. Springer International Publishing.

Alam, A. (2019). Herbs that heal: Spices- The hoard of natural remedies. Ann. Phytomed., 8(2):7-18.

Ali, A. (2020). Herbs that heal: The philanthropic behaviour of nature Ann. Phytomed., 9(1):7-17.

Ali, M. and Hakeem, K.R. (2020). Scientific explorations of Adhatoda vasica: An Asian health remedy. Springer International Publishing, Switzerland.

Alirzayeva, E.; Sirvani, T.; Ali-Zade, V.; Romheld, V. and Cakmak, I. (2011). Genetic capacity of some medicinal plants to accumulate heavy metals, in: Ahmad, A., Siddiqi, T.O., Iqbal, M. (Eds.), Medicinal plants in changing environment. Capital Publishing Company, New Delhi, pp:72-97.

Anis, M.; Varshney, A.; Fatima, N.; Khan, M.I. and Ahmad, M.R. (2014). Tissue culture technology in conservation and propagation of medicinal plants, in: Iqbal, M., Ahmad, A. (Eds.), Current trends in medicinal botany. IK International Publishing House, New Delhi, pp:271-287.
Anjum, V.; Arora P.; Ansari, S.H.; Najmi, A.K. and Ahmad, S. (2017). Antithrombocytopenic and immunomodulatory potential of metabolically characterized aqueous extract of Carica papaya leaves. Pharm. Biol., 55:2043-2056.

Ansari, M.H.R. and Ahmad, S. (2019). Herbs that heal: Natural remedies for health promotion and longevity. Ann. Phytomed., 8(1):7-18.

Attewell, G.N.A. (2007). Refiguring unani tibb: Plural healing in late colonial India. Orient Longman, Hyderabad, India.

Barrett, B.; Kiefer, D. and Rabago, D. (1999). Assessing the risks and benefits of herbal medicine: An overview of scientific evidence. Altern. Ther. Health Med., 5:40-49.

Beigh, S.Y.; Arshi, A.; Nawchoo, I.A.; Aref, I.M. and Iqbal, M. (2011). Conservation and reproductive biology of Aconitum heterophyllum and Podophyllum hexandrum, in: Ahmad, A., Siddiqi, T.O., Iqbal, M. (Eds.), Medicinal plants in changing environment. Capital Publishing Company, New Delhi, pp:142-164.

Bhoopathi, C.A. (2017). Medicinal and poisonous plants of India. MJP Publishers, Chennai, India.

Bhutya, R.K. (2011). Ayurvedic medicinal plants of India (Vol. 2), Scientific Publishers, Jodhpur, India.

Bhutya, R.K. (2018). Colour atlas of medicinal plants. Scientific Publishers, Jodhpur, India.

Black, S. (2020). COVID-19 vaccine based on peptide nanofibers shows promise. Science Advisory Board, Item 1149 (August 7, 2020) (http://www.scienceboard.net).

Brangule, A.; Šukele, R. and Bandere, D. (2020). Herbal medicine characterization perspectives using advanced FTIR sample techniques: Diffuse reûectance (DRIFT) and photoacoustic spectroscopy (PAS). Front. Plant Sci., 11:356. (DOI: 10.3389/fpls.2020.00356).

Bruah, A. (2018). Ethnobotany for human welfare, 2nd ed. Aavishkar Publishers, Jaipur, India.

Carstensen, J.T. and Rhodes, C.T. (2000). Drug stability: Principles and practices, 3rd ed, Marcel Dekker Inc., New York, USA.

CCRUM (2006). National formulary of unani medicine, Part 1. Central Council for Research in Unani Medicine (Govt. of India), New Delhi, pp:109-110, 178, 188, 210, 299.

Chakraborty, P. (2018). Herbal genomics as tools for dissecting new metabolic pathways of unexplored medicinal plants and drug discovery. Biochim. Open., 6:9-16

Chandra, K.; Khan, W.; Jetley, S.; Ahmad, S. and Jain, S.K. (2018). Antidiabetic, toxicological, and metabolomic profiling of aqueous extract of Cichorium intybus seeds. Pharmacogn. Mag., 14:377-383.

Chandra, S.; Lata, H. and Verma, A. (2013). Biotechnology for medicinal plants: Micropropagation and improvement. Springer-Verlag, Berlin, Heidelberg.

Chaudhary, A.A.; Ahmad, A. and Iqbal, M. (2014). Molecular biology techniques for authentication of medicinal plants, in: Iqbal, M., Ahmad, A. (Eds.), Current trends in medicinal botany, IK International Publishing House, New Delhi, pp:311-345.

Chaudhary, R. and Rafei, U.M. (2002). Traditional medicine in Asia. World Health Organization, Regional Office for South-East Asia, New Delhi, India.

Chaves, D.S.A. (2020). The importance of the pet market for the development of new products based on medicinal plants and their derivatives. Ann. Phytomed., 9(1):1-6. 
Chester, K.; Paliwal, S.; Khan, W. and Ahmad, S. (2017). UPLC-ESI-MS/MS and HPTLC method for quantitative estimation of cytotoxic glycosides and aglycone in bioactivity guided fractions of Solanum nigrum L. Front. Pharmacol., 8:434. (DOI: 10.3389/fphar.2017.00434).

Dasgupta, A. and Hammett Stabler, C.A. (2010). Herbal supplements: Efficacy, toxicity, interactions with western drugs, and effects on clinical laboratory tests. John Wiley and Sons, Inc.

Davis, J.S. (1991). Criteria for accelerated stability testing. Presentation in FDA/ASQ Seminar, March 11, Chicago, USA.

Dhiman, A.; Sharma, A.; Sharma, K. and Sindhu, P. (2016). A review on the status of quality control and standardization of herbal drugs in India. Drug Dev. Ther., 7:107-112.

Dhiman, K.S. (2017). Medicobotany of Andaman and Nicobar islands Recent study. Central council of research in ayurvedic sciences, New Delhi, India.

Ehlting, J.; Büttner, D.; Wang, Q.; Douglas, C.J.; Somssich, I.E. and Kombrink, E. (1999). Three 4-coumarate: Coenzyme a ligases in Arabidopsi thaliana represent two evolutionarily divergent classes in angiosperms Plant J., 19:9-20.

Fahim, M.; Ibrahim, M.; Zahiruddin, S.; Parveen, R.; Khan, W.; Ahmad, S.; Shrivastava, B. and Shrivastava, A.K. (2019). TLC-bioautography identification and GC-MS analysis of antimicrobial and antioxidant active compounds in Musa $\times$ paradisiaca $\mathrm{L}$. fruit pulp essential oil. Phytochem. Analysis, 30:332-345.

Farooqi, A.H.A. and Haque, S. (2011). Secondary metabolite production of medicinal and aromatic plants as influenced by nutrients and heavy metals, in: Ahmad, A., Siddiqi, T.O., Iqbal, M. (Eds.), Medicinal plants in changing environment. Capital Publishing Company, New Delhi, pp:35-49.

Farooqui, A.A. and Sreeramu, B.S. (2004). Cultivation of medicinal and aromatic crops. Orient Blackswan, Hyderabad.

Gaston, K.J. and Kunin, W.E. (1997). Rare-common differences: An overview, in: Kunin, W.E., Gaston, K.J. (Eds.), The Biology of rarity. Chapman and Hall, London, pp:262-272.

Gaurav, S.S. and Gaurav, N.S. (2014). Indian herbal drug microscopy. Springer, New York.

Geelani, G. (1995). Kitab-ul-Kulliyaat, 1st ed. Ejaz Publishing House New Delhi, pp:427-431.

Ghani, A. (2013). Herbal medicines: Present status, future prospects The Pharma World pp:4. (www.pharmabiz.com).

Gupta, V.K. (2014). Traditional and folk herbal medicine. Daya Publishing House, New Delhi, India.

Gurib-Fakim, A. (2006). Medicinal plants: Traditions of yesterday and drugs of tomorrow. Mol. Asp. Med., 27:1-93.

Hakeem, K.R.; Abdul, W.M.; Hussain, M.M. and Razvi, S.S.I. (2019). Oral health and herbal medicine, Springer International Publishing.

Hashiguchi, A.; Tian, J. and Komatsu, S. (2017b). Proteomic contribution to medicinal plant research: From plant metabolism to pharmacological action. Proteomes, 5(4):35. (https://doi.org/10.3390/proteomes5040035).

Hashiguchi, A.; Zhu, W.; Tian, J. and Komatsu, S. (2017)a. Proteomics and metabolomics-driven pathway reconstruction of mung bean for nutraceutical evaluation. Biochim. Biophys. Acta, 1865:1057-1066.

I.D.M.A. (2002). Indian herbal pharmacopoeia, Vols. I and II, IDMA, Mumbai, India.
Iqbal, M. (2013). From medicine to phytomedicine. Ann. Phytomed., 2:1-2.

Iqbal, M. (2018). Botanical identity of traditional herbal drugs. Academic Staff College, JMI, New Delhi, India.

Iqbal, M. and Ahmad, A. (2014). Current trends in medicinal botany. IK International, New Delhi, India.

Iqbal, M. and Srivastava, P.S. (1997). Some aspects of medicinal plant research that merit attention, in: Sharma, D. (Ed.), Compendium on phytomedicines. Council for Development of Rural Areas, CSIR Publications, New Delhi, pp:424-436.

Iqbal, M.; Ahmad, A. and Siddiqi, T.O. (2011a). Characterization of controversial plant drugs and effect of changing environment on active ingredients, in: Ahmad, A., Siddiqi, T.O., Iqbal, M. (Eds.), Medicinal plants in changing environment. Capital Publishing Company, New Delhi, pp:1-10

Iqbal, M.; Mahmooduzzafar; Nighat, F. and Aref, I.M. (2011b). Composition of seed oils of Peristrophe bicalyculata and Ruellia tuberosa as affected by coal-smoke stress. J. Food Agric. Environ., 9:1101-1104.

Iqbal, M.; Parveen, R.; Parveen, A.; Parveen, B. and Aref, I.M. (2018). Establishing the botanical identity of plant drugs based on their active ingredients under diverse growth conditions. J. Environ. Biol., 39: $123-136$

Islam, M.N. (2017). Chinese and Indian medicine today, Springer Nature, Singapore.

Jackson, W. and Sutherland, L.A. (2000). Botanic garden conservation international, data base, UK.

Jan, S. and Abbas, N. (2018). Himalayan phytochemicals: Sustainable options for sourcing and developing bioactive compounds. Elsevier Inc.

Joshi, D.D. (2012). Herbal drugs and fingerprints: Evidence-based herbal drugs, Springer India, New Delhi.

Joshi, M.C. (2007). Handbook of Indian medicinal plants. Scientific Publishers, Jodhpur, India.

Kamil, M. (2014). Herbal medicines interactions, in: Iqbal, M., Ahmad, A. (Eds.), Current trends in medicinal botany. IK International Publishing House, New Delhi, pp:142-157.

Karron, J.D. (1997). Genetic consequences of different patterns of distribution and abundance, in: Kunin, W.E., Gaston, K.J. (Eds.), The Biology of rarity. Chapman and Hall, London. pp. 175-189.

Katiyar, C.K. and Khare, C.P. (2018). Ayurveda at the turning point. Kruger Brentt Publishers UK Ltd., Middlesex, UK.

Keller, K.; Hansel, R. and Chandler, R.F. (1992, 1993, 1997). Adverse effects of herbal drugs (A series of 3 volumes), Springer, Berlin.

Khan, I.A. and Khanum, A. (1998-2009). Role of biotechnology in medicinal and aromatic plants (22-Volume series), Ukaaz Publications, Hyderabad, India.

Khan, I.A. and Khanum, A. (2004, 2005, 2005, 2007). Ethnomedicine and human welfare (4-Volume series), Ukaaz Publications, Hyderabad, India.

Khan, I.A. and Khanum, A. (2005, 2007, 2007, 2008). Herbal medicine for human diseases (4-Volume series), Ukaaz Publications, Hyderabad, India.

Khan, S. (2011). Authentication of medicinal plants: Phyllanthus amarus, in: Ahmad, A., Siddiqi, T.O., Iqbal, M. (Eds.), Medicinal plants in changing environment. Capital Publishing Company, New Delhi, pp:224-248 
Khan, W.; Gupta, S. and Ahmad, S. (2017). Toxicology of the aqueous extract from the flowers of Butea monosperma Lam. and it's metabolomics in yeast cells. Food Chem. Toxicol., 108:486-497.

Khan, W.; Parveen, R.; Chester, K.; Parveen, S. and Ahmad, S. (2017) Hypoglycemic potential of aqueous extract of Moringa oleifera leaf and in vivo GC-MS metabolomics. Front. Pharmacol., 8:577. (DOI: 10.3389/fphar.2017.00577).

Khanum, A.; Rehman, S. and Jabeen, U. (2014). Peptides: An emerging source of drugs/medicines, in: Iqbal, M., Ahmad, A. (Eds.), Current trends in medicinal botany. IK International Publishing House, New Delhi, pp:371-393.

Khare, C. (2004). Indian herbal medicines. Springer, Berlin.

Khare, C.P. (2004). Indian herbal remedies: Rational western therapy, ayurvedic and other traditional usage, botany. Springer, Berlin.

Khare, C.P. (2007). Indian medicinal plants: An illustrated dictionary. Springer Nature, Singapore.

Khare, C.P. (2018). World healing plants for tomorrow. Daya Publishing House, New Delhi, India.

Kleinwächter, M. and Selmar, D. (2015). New insights explain that drought stress enhances the quality of spice and medicinal plants: Potential applications. Agron. Sustain. Dev., 35:121-131.

Kumar, M.R. and Janagam, D. (2011). Export and import pattern of medicinal plants in India. Indian J. Sci. Technol., 4:245-248.

Lee, Y.S.; Park, H.S.; Lee, D.K.; Jayakodi, M.; Kim, N.H.; Koo, H.J.; Lee, S.C.; Kim, Y.J.; Kwon, S.W. and Yang, T.J. (2017). Integrated transcriptomic and metabolomic analysis of five Panax ginseng cultivars reveals the dynamics of ginsenoside biosynthesis. Front. Plant Sci., 8:1048.

Maiti, B.; Nagori, B.P. and Singh, R. (2011). Recent trends in herbal drugs: A review. Int. J. Drug Res. Technol., 1:17-25.

Majid, U.; Mahmooduzzafar; Siddiqi, T.O.; Aref, I.M. and Iqbal, M. (2013) Quantitative changes in proteins, pigments and sennosides of Cassia angustifolia Vahl. treated with Mancozeb. Pak. J. Bot., 45:1509-1514.

Mallick, M.N.; Khan, W.; Parveen, R.; Ahmad, S.; Sadaf; Najm, M.Z.; Ahmad, I. and Husain, S.A. (2017). Exploring the cytotoxic potential of triterpenoids-enriched fraction of Bacopa monnieri by implementing in vitro, in vivo, and in silico approaches. Pharmacogn. Mag., 13:595-606

Mangathayaru, K. (2013). Pharmacognosy: An Indian perspective. Pearson Education, India.

Marichamy, K.; Kumar, N.Y. and Ganesan, A. (2014). Sustainable developmen in exports of herbals and Ayurveda, Siddha, Unani and Homoeopathy (AYUSH) in India. Sci. Park Res. J., 1:1-6.

McNeely, J.A. (1988). Economics and biological diversity: Developing and using economic incentives for conserving biological resources. IUCN Publications, Gland.

Melchinger, A.E. (1999). Genetic diversity and heterosis, in: Coors, J.G. (Ed.), The genetic diversity and exploitation of heterosis in crops. ASA-CSSA-SSSA, Madison, USA. pp:99-109.

Mohan, V.R.; Doss, A.; Tresina, P.S. and Sornalakshmi, V. (2018). Ethnomedicina plants: A biodiversity treasure. Daya Publishing House, New Delhi, India.

Mohanraj, K.; Karthikeyan, B.S.; Vivek-Ananth, R.P.; Bharath Chand, R.P.; Aparna, S.R.; Mangalapandi, P. and Sama, A. (2018). IMPPAT: A curated database of Indian medicinal plants, phytochemistry and therapeutics. Sci. Rep., 8:4329. (DOI: 10.1038/s41598-018-22631-z).
M.R.F.R. (2019). Report on global marketing of herbal medicine-2019. Market Research Future, Pune, India.

Mukherjee, P.K. (2015). Evidence-based validation of herbal medicine. Elsevier Inc.

Mukharjee, P.K. (2019). Quality control and evaluation of herbal drugs. Elsevier Inc.

Mukherjee, P.K.; Venkatesh, M. and Kumar, V. (2007). An overview on the development in regulation and control of medicinal and aromatic plants in the Indian system of medicine. Bol. Latinoam. Caribe Plantas Med. Aromát., 6:129-136.

Naeem, M.; Aftab, T. and Khan, M.A. (2017). Catharanthus roseus: Current research and future prospects. Springer Nature, Switzerland.

Natesh, S. (2000). Biotechnology in the conservation of medicinal and aromatic plants, in: Chadha, K.L., Ravindran, P.N., Lela, S. (Eds.), Biotechnology on horticultural and plantation crops. Malhotra Publishing House, New Delhi. pp:548-561.

N.B.A. (2012). National biodiversity authority. Annual Report 2011 2012, Chennai. Available at: http://nbaindia.org/uploaded/pdf/ Annual_Report_2011_12_\%20Eng.pdf.

N.I.I.R. (2004). Handbook on Unani medicine with formulae, processes, uses and analysis. National Institute of Industrial Research, Asia Pacific Business Press, Delhi.

Noor-ul-Basar, S.; Rani, M. and Zaman, R. (2013). A review on stability studies of unani formulations. J. Pharm. Sci. Innov., 2:1-8.

Olorode, O. (2004). Conservation of plant genetic resources. Afr. J. Trad. Complement. Altern. Med., 1:4-14.

Öztürk, M.; Altay, V.; Hakeem, K.R. and Akçiçek, E. (2017). Licorice: From botany to phytochemistry. Springer International Publishing, Netherlands.

Öztürk, M. and Hakeem, K.R. (2018). Plants and human health Vol. 1 (Ethnobotany and physiology). Springer International Publishing, Switzerland.

Öztürk, M. and Hakeem, K.R. (2019). Plants and human health Vol. 2 (Phytochemistry and molecular biology). Springer International Publishing, Switzerland

Öztürk, M. and Hakeem, K.R. (2019). Plants and human health Vol.3 (Pharmacology and theraputics). Springer International Publishing, Switzerland.

Pandey, A.; Rath, B. and Dwivedi, A.K. (2011). Pharmaceutical pre-formulation studies with special emphasis on excipients compatibility. Int. J. Pharm. Technol., 3:1029-1048.

Parveen, A.; Parveen, R.; Akhatar, A.; Parveen, B.; Siddiqui, K.M. and Iqbal, M. (2020). Concepts and quality considerations in Unani system of medicine. J. AOAC Int., 103:284. doi: org/10.5740/jaoacint.19-0284.

Parveen, A.; Ahmad, M.; Parveen, B.; Parveen, R. and Iqbal, M. (in press). Traditional system of Unani medicine, its origin, evolution and Indianization: A critical appraisal. Indian J. Trad. Knowl. (in press)

Parveen, R.; Ahmad, F.J. and Iqbal, Z. (2014). Potential botanicals for the treatment of breast cancer: Pharmaceutical approaches used to increase the absorption of herbal drugs, in: Iqbal, M., Ahmad, A. (Eds.), Current trends in medicinal botany. IK International Publishing House, New Delhi. pp:109-129.

Parveen, R.; Baboota, S.; Ali, J.; Ahuja, A.; Vasudev, S.S. and Ahmad, S. (2011). Oil-based nano-carrier for improved oral delivery of silymarin: In vitro and in vivo studies. Int. J. Pharm., 413:245-253. 
Parveen, R.; Parveen, B.; Parveen, A. and Ahmad, S. (2019). Andrographis paniculata: From traditional to nano drug for cancer therapy, in: Husen, A., Iqbal, M. (Eds.), Nanomaterials and plant potential. Springer Nature, Switzerland. pp:317-345.

Parveen, S.; Ansari, M.H.R.; Parveen, R.; Khan, W.; Ahmad, S. and Husain, S.A. (2019). Chromatography-based metabolomics and in silico screening of Gymnema sylvestre leaf extract for its antidiabetic potential. Evid.-Based Complementary Altern. Med., 2019:7523159. (DOI: org/10.1155/2019/7523159).

Patwardhan, B. (2007). Drug discovery and development: Traditional medicine and ethnopharmacology. Aavishkar Publishers, Jaipur, India.

Patwardhan, B.; Vaidya, A.D.B. and Chorghade, M. (2004). Ayurveda and natural products drug discovery. Curr. Sci., 86:789-799.

Patwardhan, B.; Warude, D.; Pushpangadan, P. and Bhatt, N. (2005). Ayurveda and traditional Chinese medicine: A comparative overview. Evidbased Comp. Altern. Med., 2(4):465-473.

P.B.W. (2018). Can indian traditional medicinal systems show the way forward? Pharma Bio World, Dec 2018 (Available at www.magzter.com).

P.C.I.M.H. (2009). The Unani pharmacopoeia of India, Part I: Single drugs (6 Vols). Pharmacopoeia Commission for Indian Medicine and Homeopathy, Dept. of AYUSH, Government of India, New Delhi.

P.C.I.M.H. (2016). The Ayurvedic pharmacopoeia of India, Part I: Single drugs (9 Vols). Pharmacopoeia Commission for Indian Medicine and Homeopathy, Ministry of AYUSH, Government of India, New Delhi.

P.C.I.M.H. (2017). The Ayurvedic pharmacopoeia of India, Part II: Formulations (4 Vols). Pharmacopoeia Commission for Indian Medicine and Homeopathy, Ministry of AYUSH, Government of India, New Delhi.

P.C.I.M.H. (2019). The Unani pharmacopoeia of India, Part II: Formulations (4 Vols). Pharmacopoeia Commission for Indian Medicine and Homeopathy, Ministry of AYUSH, Government of India, New Delhi.

Plaza, M.; Pozzo, T.; Liu, J.; Gulshan Ara, K.Z.; Turner, C. and Karlsson, N.E. (2014). Substituent effects on in vitro antioxidizing properties, stability, and solubility in flavonoids. J. Agric. Food Chem., 62:33213333 .

Prasad, M.N.V.; Padmalatha, K.; Jayaram, K.; Raju, N.L. and Teixeira da Silva, J.A. (2007). Medicinal plants from deccan ecoregion, India: Traditional knowledge, ethnopharmacology, cultivation, utilization, conservation and biotechnology: Opportunities and impediments. Med. Arom. Plant Sci. Biotechnol., 1:155-208.

Prasad, M.N.V.; Padmalatha, K.; Jayaram, K. and Raju, N.L. (2011). Relevance of biotechno-logical tools for conservation of plant resources, in: Ahmad, A., Siddiqi, T.O., Iqbal, M. (Eds.), Medicinal Plants in Changing Environment. Capital Publishing Company, New Delhi, India. pp:213-246.

Prudente, D.O. and Paiva, R. (2017). Plant cryopreservation: Biochemica aspects. J. Cell Develop. Biol., 1(1):2.

Pullaiah, T. (2019). Encyclopaedia of world medicinal plants, (7 Vols), second ed. Regency Publications, New Delhi, India.

Pushpangadan, P.; George, V. and Dan, V.M. (2014). Biodiversity, bioprospecting, IPR and benefit sharing with stakeholders in the $21^{\text {st }}$ century, in: Iqbal, M., Ahmad, A. (Eds.), Current trends in medicinal botany. IK International Publishing House, New Delhi, pp:130-141.
Qureshi, M.I.; Abdin, M.Z.; Ahmad, J. and Iqbal, M. (2013). Effect of longterm salinity on cellular antioxidants, compatible solute and fatty acid profile of sweet annie (Artemisia annua L.). Phytochemistry, 95:215-223.

Qureshi, M.I.; Iqbal, M. and Abdin, M.Z. (2011). Lead and salinity stress in plants with special reference to Artemissia annua and Cassia angustifolia, in: Ahmad, A., Siddiqi, T.O., Iqbal, M. (Eds.), Medicinal plants in changing environment. Capital Publishing Company, New Delhi, pp:109-139.

Raaman, N. (2006). Phytochemical techniques. New India Publishing Agency (NIPA), New Delhi, India.

Rahman, M.; Beg, S.; Kumar, V. and Ahmad, FJ. (2020). Nanomedicine for bioactives: Healthcare applications. Springer, Singapore.

Rajpal, V. (2004). Standardization of botanicals. Testing and extraction methods of medicinal herbs, Vol. I. Eastern Publisher, New Delhi.

Ramawat, K.G. (2009). Herbal drugs: Ethnomedicine to modern medicine. Springer, Berlin.

Rani, S.; Rahman, K.; Younis, P.M. and Shadab, M. (2015). Shelf life of Unani drugs in classical and contemporary era. Res. Rev. J. Unani, Siddha Homeo., 2:26-35.

Saad, B. and Said, O. (2011). Greco arab and Islamic herbal medicine: Traditional system, ethics, safety, efficacy, and regulatory issues. John Wiley and Sons, Inc.

Sahoo, N. and Manchikanti, P. (2013). Herbal drug regulation and commercialization: An Indian industry perspective. J. Altern. Comp. Med., 19:957-963

Sahoo, N., Mancjkanti, P. and Dey, S.H. (2010). Herbal drugs standards and regulation. Fitoterapia, 81:462-471.

Schmidt-Stiedenroth, K. (2020). Unani medicine in the making: Practices and representations in $21^{\text {st }}$ century India. Amsterdam University Press, Amsterdam, Netherlands.

Sekeroglu, N. (2019). Some customary edible plants of incredible medicinal worth. Ann. Phytomed., 8(2):1-6.

Selmar, D. and Kleinwächter, M. (2013). Influencing the product quality by deliberately applying drought stress during the cultivation of medicinal plants. Ind. Crop Prod., 42:558-566.

Sen, S.; Chakraborty, R. and De, B. (2011). Challenges and opportunities in the advancement of herbal medicine: India's position and role in a global context. J. Herb. Med., 1:67-75.

Sen, S. and Chakraborty, R. (2014). Traditional knowledge digital library: A distinctive approach to protect and promote Indian indigenous medicinal treasure. Curr. Sci., 106:1340-1343.

Sen, S. and Chakraborty, R. (2015). Toward the integration and advancement of herbal medicine: A focus on traditional Indian medicine. Botanics, 5:33-44

Sen, S. and Chakraborty, R. (2020). Herbal medicine in India: Indigenous knowledge practice, innovation and its value. Springer Nature, Singapore.

Seth, A. (2005). The herbs of ayurveda (4 Vols). Sheth Brothers, Bhavnagar (Gujarat), India.

Shaheen, S.; Ramzan, S.; Khan, F. and Ahmad, M. (2019). Adulteration in herbal drugs: A burning issue. Springer International Publishing. 
Sharma, I.; Khan, W.; Parveen, R.; Alam, M.J.; Ahmad, I.; Ansari, M.H.R. and Ahmad. S. (2017). Antiurolithiasis activity of bioactivity-guided fraction of Bergenia ligulata against ethylene glycol induced renal calculi in rat. Biomed Res. Int., 2017:1969525. (DOI: 10.1155/ 2017/1969525, 28349055).

Sharma, R. (2018). Agrotechniques of medicinal plants. Daya Publishing House, New Delhi, India.

Simopoulos, A.P. and Gopalan, C. (2003). Plants in human health and nutrition policy. Karger AG, Bacel, Switzerland.

Singh, B. and Peter, K.V. (2018). New age herbals: Resource, quality and pharmacognosy. Springer Nature, Singapore.

Singh, H. (2007). Prospects and challenges for harnessing opportunities in medicinal plants sector in India. Law Environ. Develop. J., 2:196-211.

Singh, J.; Meshram, V. and Gupta, M. (2020). Bioactive natural products in drug discovery. Springer, Singapore.

Singh, J. and Yadav A.N. (2020). Natural bioactive products in sustainable agriculture. Springer, Singapore.

Singh, M.P. (2018). Wild medicinal plants, 2nd ed. Daya Publishing House, New Delhi, India.

Singh, V. (2007). Indian folkmedicine and other plant-based products. Scientific Publishers, Jodhpur, India.

Singh, V. (2009). Ethnobotany and medicinal plants of India and Nepa (Vol. 3), Scientific Publishers, Jodhpur, India.

Stavroula, M. and Rahul, J. (2016). Mediterranean climate affects the biosynthesis of secondary metabolites in common medicinal plants. Int. J. Bot., 6:17-28

Tahtamouni, R.W.; Shibli, R.A.; Al-Abdallat, A.M.; Al-Qudah, T.S.; Laila Younis, L.; AlBaba, H. and Al- Ruwaiei, H. (2015). In vitro conservation and cryopreservation of medicinal and aromatic plants: A review. Jordan J. Agric. Sci., 11:147-167.

Taiz, L. and Zeiger, E. (2010). Plant physiology, 3rd ed. (Chapter: Stress physiology). Sinauer Associates, Sunderland, MA.

Thangavel, K.; Ebbie, M.G. and Ravichandran, P. (2014). Biotechnology and in vitro conservation of medicinal plants. Ann. Plant Sci., 3:734-744.
Trivedi, P.C. (2004). Herbal drugs and biotechnology. Pointer Publishers, Jaipur, India.

Trivedi, P.C. (2006). Herbal medicine: Traditional practices. Avishkar Publishers, Jaipur, India.

Trivedi, P.C. (2006). Medicinal plants: Traditional knowledge. IK International, New Delhi.

Trivedi, P.C. (2007). Ethnomedicinal plants of India. Avishkar Publishers, Jaipur, India.

USP-N.F. (2018). The United States pharmacopeia $41+$ National formulary 36. 1st Vol. US Pharmacopeial Convention Inc., Rockville, MD (US).

Vaidya, A.D.B and Devasagayam, T.P.A. (2007). Current status of herbal drugs in India: An overview. J. Clin. Biochem. Nutr., 41:1-11.

Vardhana, R. (2008). Direct uses of medicinal plants and their identification. Sarup and sons, New Delhi.

Verpoorte, R. and Mukharjee, P.K. (2003). GMP for botanicals - Regulatory and quality issues on phytomedicine, first ed, Business Horizons, New Delhi.

Wakdikar, S. (2004). Global healthcare challenge: Indian experiences and new prescriptions. Electron. J. Biotechnol., 7:214-220.

Walter, L. (1994). The pharmaceutical codex-principles and practice of pharmaceutics, twelfth ed. The Pharmaceutical Press, UK, pp:277-288.

W.H.O. (2019). Global report on traditional and complementary medicine-2019. World Health Organization, Geneva.

Yuan, H.; Ma, Q.; Ye, L. and Piao, G. (2016). The traditional medicine and modern medicine from natural products. Molecules, 21:559. (DOI: 10.3390/molecules21050559).

Zahiruddin, S.; Khan, W.; Nehra, R.; Alam, M.J.; Mallick, M.N.; Parveen, R. and Ahmad, S. (2017). Pharmacokinetics and comparative metabolic profiling of iridoid enriched fraction of Picrorhiza kurroa: An Ayurvedic Herb. J. Ethnopharmacol., 197:157-164.

Zawar, S.N. (2011). Medicinal plants: Holistic approaches. New India Publishing Agency, New Delhi, India.

Zaynab, M.; Fatima, M.; Abbas, S.; Sharif, Y.; Jamil, K.; Ashraf, A.; Aslam, M.M.; Shabbir, A. and Batool, W. (2018). Proteomics approach reveals importance of herbal plants in curing diseases. Int. J. Mol. Microbiol., 1:23-28. 